\title{
Analysis of the Philosophical, Sociological and Juridical Basis for Amendment to Regional Regulations of Bogor Regency Concerning Public Service Retribution on Waste/Cleanliness
}

\author{
Nazaruddin Lathif; Suhermanto; Mustika Mega Wijaya; Sapto Handoyo Dp \\ Lecturer of the Faculty of Law at Pakuan University, Indonesia \\ http://dx.doi.org/10.18415/ijmmu.v8i6.2733
}

\begin{abstract}
Regional taxes and levies are part of the source of Regional Original Income or better known as (PAD), which is a regional asset that is part of the income of a region. The type of research used in this legal research is empirical normative legal research, namely research based on primary, secondary and tertiary legal materials with interpretation and systematization between laws and regulations. it is necessary to adjust the retribution rate, especially regarding the general service retribution regarding cleaning/waste services. This is as explained in Article 155 paragraph (1) of Law Number 28 of 2009 concerning Regional Taxes and Regional Levies, which states that the Levy Tariff is reviewed at the latest every 3 (three) years. So here it is very clear for Regional Regulations that many regions have not updated their rules, and are expected to be re-evaluated due to economic developments and also the price index.
\end{abstract}

Keywords: Levies; Local Regulations; Solid Waste; Local Taxes

\section{Introduction}

The purpose of the state is stated in the fourth paragraph of the constitution, namely the Preamble to the 1945 Constitution of the Republic of Indonesia (UUD 1945) which identifies that the Indonesian state is a legal state whose goal is to realize general welfare. Every activity or activity must be in accordance with applicable law which is a rule of state, government and community activities that must be obeyed and also do not forget to focus on the goals to be achieved and must be oriented towards the goals to be achieved.

The 1945 Constitution or the 1945 Constitution has regulated Regional Government at the provincial, Regency and City levels, which are stated in the provisions of Article 18, in Article 18 paragraph (1) of the 1945 Constitution, it is explained that the Unitary State of the Republic of Indonesia or Known as the Unitary State of the Republic of Indonesia, it is divided into provincial areas, which are then divided into regencies or cities, which then each province, regency, or city has a regional government, which is then regulated in a law, specifically the Law on Regional Government. Regional 
government is expanded based on the principle of autonomy (decentralization) and co-administration (Asshiddiqie, 2011, p. 220). The provisions of Article 18 paragraph (1) of the 1945 Constitution, show that the implementation of regional government in Indonesia is known as the unitary value and also the value of territorial decentralization which is the 2 (two) basic values carried out in the Indonesian state. (Subarno, 2008, p. 3)

The regulation of regional government in the constitution becomes the momentum for the implementation of the regional autonomy system. Article 18 paragraph (2) of the 1945 Constitution explains that both the provincial government, city and district governments can regulate and manage their own affairs, which consist of government affairs which are carried out according to the principle of autonomy as well as assistance tasks carried out by the government. all of which are regulated in the Law on Regional Government. To improve a welfare and service to the community that is getting better, then democratic life, equity, justice, and the maintenance of relations between the central government and the regions, all of which are the goals of regional autonomy itself. (Lathif, 2021)

Regional taxes and levies are part of the source of Regional Original Income or better known as (PAD), which is a regional asset that is part of the income of a region. There is a fundamental difference between regional taxes and regional levies. The difference is that regional tax is a mandatory contribution charged to individuals or individuals personally or to entities that are paid to the region, without any compensation, and its nature can be imposed based on the provisions of laws and regulations, the purpose of which is to finance regional development and administration of government. Area. In contrast to levies, levies are categorized as a levy taken by the region as a payment for services or the granting of certain permits that are specifically given by the regional government to individuals or entities that are determined based on Regional Regulations (Perda) which must not conflict with the provisions of the legislation. which is above it. (Syarifin and Jubaedah, 2005, p. 260)

\section{Research Method}

Research is a basic tool in the development of science and technology. This is because the research aims to reveal the truth systematically, methodologically, and consistently. The type of research used in this legal research is empirical normative legal research, namely research based on primary, secondary and tertiary legal materials with interpretation and systematization between laws and regulations. Normative legal research is supported by empirical research to obtain primary data. A normative approach is used, namely the study of document studies on laws and regulations and various policies related to the subject matter, namely those relating to the Waste/Cleaning Charges in the Bogor Regency area, with the aim of looking at problems related to the Waste/Cleaning Charges and also by looking at the reports on the results of various meetings. As well as an empirical approach carried out by conducting Focus Group Discussions (FGD) and public consultations (public hearings).

\section{Discussion}

\section{Public Service Retribution on Waste/Cleaning Services}

The definition of regional levies contained in Chapter 1 of General Provisions, Article 1 number 64 of Law Number 28 of 2009 concerning Regional Taxes and Regional Levies, is a regional levy as payment for services or the granting of certain permits specifically provided and/or granted by Regional Government for the benefit of individuals or entities.

The purpose of regional levies is to fill the state treasury finances and regional treasuries to meet their needs. According to Law Number 28 of 2009 concerning Regional Taxes and Regional Levies as stated in Chapter VI Part One concerning Objects and Classes of Charges Article 108, Objects of Charges 
are levies for services provided or provided by local governments. Regarding this, that not everything provided by the regional government can be levied, but there are only certain types of services which according to socio-economic considerations are worthy of being used as objects of retribution. To establish general policies regarding the principles and targets in setting levy rates. In Article 108 paragraph (1) of Law Number 28 of 2009 divides user fees into 3 (three) groups, namely general service fees, business service fees and certain licensing fees.

Regarding the definition of Public Service Retribution, it is regulated through Chapter 1 General Provisions, Article 1 point 66 of Law Number 28 of 2009 concerning Regional Taxes and Regional Levies, which states that Public Service Retribution is a levy on services provided or provided by the Regional Government for the purpose of and public benefits and can be enjoyed by private persons or entities.

a. General Service Retribution Subject

The subject of Public Service Retribution is regulated in Article 125 of Law Number 28 of 2009 concerning Regional Taxes and Regional Levies. The subject of the Public Service Retribution is an individual or entity that uses or enjoys the public service concerned. The subject of this public service levy may be a mandatory public service levy.

\section{b. General Service Retribution Object}

The object of Public Service Retribution is regulated in Article 109 of Law Number 28 of 2009 concerning Regional Taxes and Regional Levies. Objects for public service levies are services provided by local governments for the purpose of public interest and benefit and can be enjoyed by individuals or entities.

\section{c. Types of General Service Retribution}

Types of Public Service Retribution are regulated in Article 110 paragraph (1) of Law Number 28 of 2009 concerning Regional Taxes and Regional Levies. The types of public service levies can be mentioned as follows, one of which is regarding the Garbage/Cleaning Service Retribution.

Public Service Retribution on Waste/Cleaning Services is regulated in Article 112 paragraph (1) and paragraph (2) of Law Number 28 of 2009 concerning Regional Taxes and Regional Levies. Objects for Retribution for Waste/Cleaning Services as referred to in Article 110 paragraph (1) letter b are waste/cleaning services organized by the Regional Government, including:

1. Garbage collection/collection from its source to a temporary disposal site;

2. Transportation of waste from the source and/or temporary disposal location to the final waste disposal/disposal location; and

3. Provision of a final waste disposal/destruction location. 


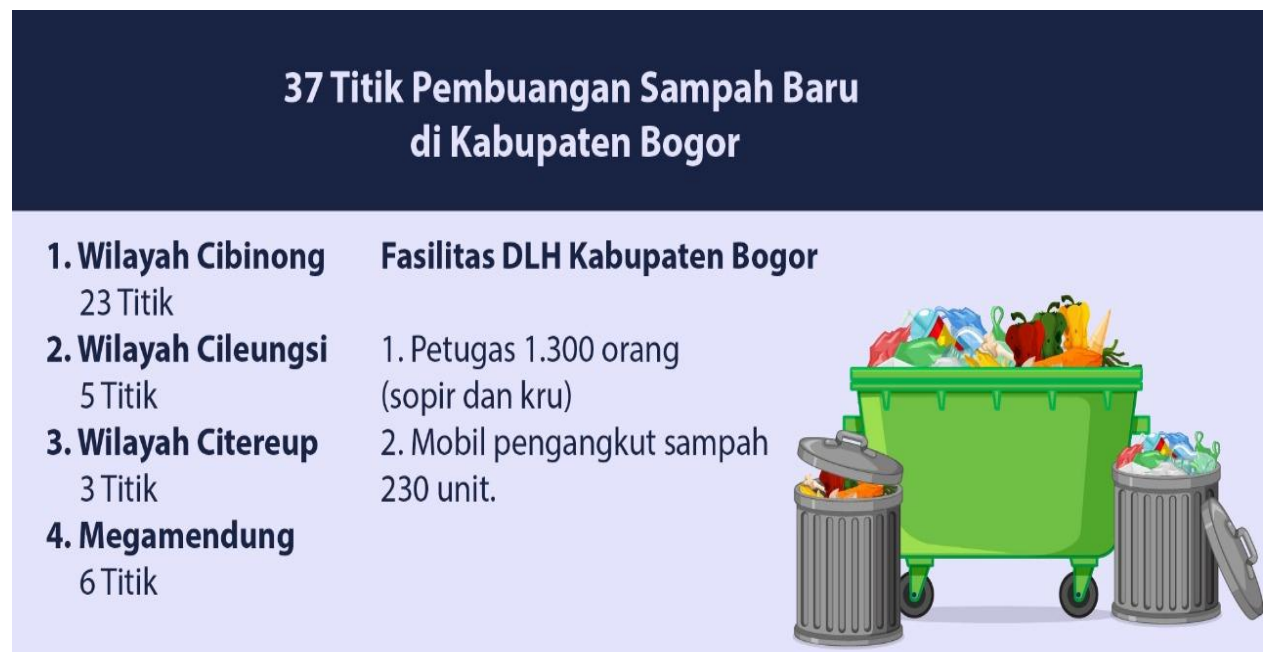

Source : https://www.radarbogor.id/2019/11/25/temukan-37-titik-pembuangan-sampah-baru-dikabupaten-bogor-terbanyak-di-cibinong/

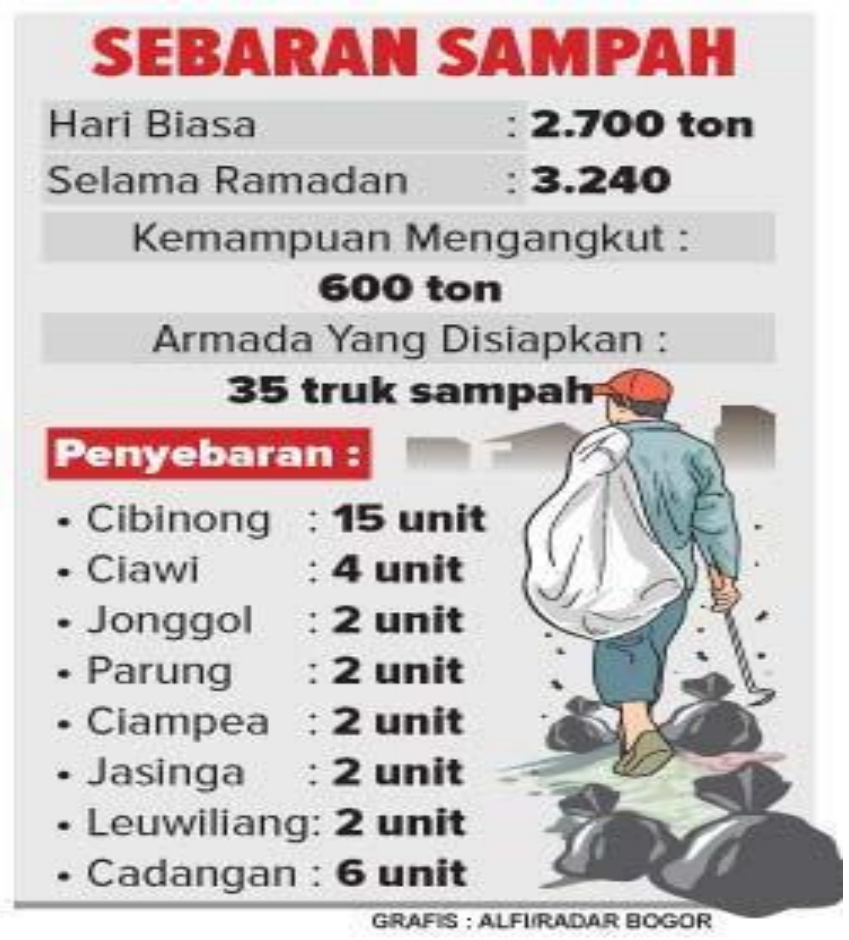

Source: https://www.radarbogor.id/2018/06/19/tumpukan-sampah-meningkat/

\section{Analysis of Legislation Reform in Philosophical, Sociological and Juridical Sides}

A regulation or regulation is an implementation of a law that can change and also dynamically follow the times. This corresponds to an unpredictable social change that is changeable and dynamic as well. In connection with a social change can not be separated from a theory of social change related to dynamic law in society and is a major theory in the field of law. The existence of social changes that result in legal changes is an interaction relationship between the two. This is better known as social engineering, namely the function of law as a means of social change, where this occurs because of a legal change which can affect social change in line with one of the functions of law. So, law is a tool of social 
engineering or better known as the means of community engineering, and is a term that was first coined by an American legal expert, Roscou Pound. (Fuady, 2014, p. 248)

In realizing a welfare, it must be balanced with an action with the aim of obtaining or achieving that welfare, both welfare which is implemented by the government and by the community itself. And to achieve this, a basic guideline or reference is needed, namely law, because the state of Indonesia is a state of law, where every citizen or government that takes action must be based on law. In the implementation of the concept of welfare or the welfare state, the role of the government is very dominant compared to society where the submission of bestuurzorg (as the organizer of public welfare) is also given to the government. Therefore, the government needs to make a regulation or legislation that is used as a guide in acting which is a form of effort to prosper the community. And in drafting these laws and regulations, the values of justice and good substance values must be taken into account so that the welfare of the community can be realized. (Hoesein, 2012)

Legislation is one of the most effective instruments in law reform compared to other legal uses. Legal reforms can be planned along with the Establishment of Legislation. Legislation not only performs the function of updating existing (existing) laws and regulations but can also be used as a means of updating jurisprudence, customary law, customary law or updating old legislation. (Hoesein, 2012)

In relation to the calculation of the amount of the waste retribution rate, it is based on the waste services carried out, where each region has updated the pattern of impact services after the issuance of Law Number 18 of 2008 concerning Waste Management. As explained in CHAPTER VI of Law Number 18 of 2008, the waste service pattern is divided into 2 (two) parts, namely (Sugara and Kustuono, 2019): Management of household waste and similar household waste Management of household waste and similar waste, consisting of:

a. Waste reduction, including activities:

1) Limitation of waste generation

2) Waste recycling; and/or

3) Waste reuse

b. Waste management, including activities:

1) Sorting in the form of grouping and separating waste according to the type, amount and/or nature of the waste;

2) Collection in the form of collection and transfer of waste from waste sources to temporary shelters or integrated waste processing sites;

3) Transportation in the form of carrying waste from the source and/or from temporary waste storage sites or from integrated waste processing sites to the final processing site;

4) Processing in the form of changing the characteristics, composition and amount of waste;

5) Final processing of waste in the form of returning waste and/or residue from previous processing to environmental media safely.

The Government and Regional Governments are required to finance the implementation of waste management, through the State Revenue and Expenditure Budget (APBN) and the Regional Revenue and Expenditure Budget (APBD) which are determined and regulated by government regulations and regional regulations. This is stated in Law Number 18 of 2008 concerning waste management, namely in Chapter VII regarding financing and compensation. Based on the above statement, it does not mean that financing in the implementation of waste management is the responsibility and must be fully facilitated or provided by the Government or by the Regional Government, but it must also be fully supported by the community through the obligation to pay user fees. The application of cross subsidies and service improvement is applied in terms of charging the public who do not entirely use the concept of cost recovery. In this 
regard, it is in line with and is also strengthened in Article 110 paragraph (2) of Law Number 28 of 2009 concerning Regional Taxes and Levies which states that types of levies may not be requested for payment if the potential revenue is small and/or on national/regional policies to provide the service is free of charge. In this regard, local governments are still allowed to collect a retribution for cleaning/waste services. (Sugara and Kustuono, 2019)

In the regulation regarding the payment of retribution for cleaning/waste services, it is known as the mandatory retribution for cleaning/garbage services, namely users of cleaning/garbage services and cleaning/garbage managers. The obligatory levy in question must be in accordance with the objectives and principles of setting levy rates. The targets and principles for determining rates for public service levies must be in accordance with Article 152 of Law Number 28 of 2009 concerning Regional Taxes and Levies, which include (Haqqi and Nugroho, 2020): First, the principles and targets for setting rates for public service levies are determined by taking into account the costs of providing the services concerned, the ability community, aspects of justice, and the effectiveness of control over these services; Second, the costs as referred to in paragraph point a include operating and maintenance costs, interest costs, and capital costs; Third, in the event that the tariff setting fully considers the cost of providing services, the tariff setting is only to cover part of the costs; Fourth, Retribution for the replacement of printing costs for Identity Cards (KTP) and Retribution reimbursement of map printing costs only takes into account printing and administration costs.

In connection with the foregoing, every regional government should update its Regional Regulations such as those related to Public Service Retribution, especially regarding waste/cleaning services, the reasons for which are divided into philosophical, sociological and juridical foundations, among others are as follows:

\section{Philosophical Foundation}

Philosophical basis, related to changes in the legal formation regarding the Waste/Cleaning Service Charges which are in the provisions of the Regional Regulation concerning General Levies, the regulation regarding the Garbage/Cleaning Service Charges is levied as payment for waste/cleaning services located in the Bogor Regency area. One form of regulation of the Waste/Cleaning Service Charges is regarding First, the Object of the Garbage/Cleaning Service Charges, namely every waste/cleaning service organized by the Regional Government, in this case the Bogor Regency which includes:

1. Garbage collection/collection from its source to a temporary disposal site;

2. Transportation of waste from its source and/or temporary disposal site to the final disposal/disposal location of waste; and

3. Provision of a location for the final disposal/destruction of waste.

Second, the subject of the levy is an individual or entity that uses/enjoys waste/cleanliness services. Mandatory levies are individuals or entities which, according to the provisions of the levy legislation, are required to pay levies, including levy collectors or withholding levies. Third, how to measure the level of service use, the level of service use is measured based on the type of service, category, volume of waste, time, building area, rate, and/or distance. Fourth, regarding the Structure and Amount of Levy Tariffs, which is determined regarding the amount of levy tariffs.

\section{Sociological Foundation}

The sociological foundation also contains an analysis of sociological-futuristic tendencies regarding the extent to which social behavior is in line with the direction and objectives of legal development to be achieved. The sociological basis requires that every legal norm set forth in a Regional 
Regulation must reflect the demands of the community's own needs for legal norms that are in accordance with the reality of public legal awareness. Therefore, in the preamble, empirical considerations must be formulated properly, so that a normative idea as outlined in the Regional Regulation is truly based on the facts that live in the legal consciousness of the community. There are several things that should be studied to determine the retribution rate, namely First, the factual condition of the regulation regarding regional levies that are determined nationally, so that adjustments must be made to the old regional regulations related to the problem of the amount of retribution rates, especially regarding the retribution for waste/cleaning services, as well as harmonization. with the regional potential.

Second, one of the elements of the rule of law is that every government/government action must be based on applicable laws and regulations. As is known, the General Retribution Regulation concerning Waste Service Retribution and wishing to make tariff adjustments must make changes in accordance with the applicable laws and regulations. This means that it must comply with the procedures for amending Regional Regulations. Third, in general, the purpose of the formation of legislation is to regulate and organize life in a country so that the people governed by the law obtain certainty, benefit and justice in the life of the state and society. Therefore, one of the main pillars in the administration of a legal state is the formation of good, harmonious, and easy-to-implement laws and regulations in society. This means that the Amendment to the General Retribution Regulation concerning Waste Service Retribution is to have legality and legal certainty to regulate the community in terms of tariff adjustments without compromising the value of benefits and also justice in it, whose main purpose is for the benefit of the community at large.

Fourth, if it is related to the type of modern welfare state adopted by the 1945 Constitution, where the government is given very broad authority to participate actively in all socio-cultural and economic fields. This means that the government is given the authority to determine the making of a regional regulation, in this case the amendment to the regional regulation on general levies regarding waste retribution, especially regarding changes in waste retribution rates that must be fenced off with good and fair legal rules, as well as supervision so as not to cause arbitrariness.

Fifth, the determination of levies must pay attention to the economic aspects, related to levies, there are elements of services from the government to the community and which become the benchmark for retribution, one of which: (a) can be collected effectively; (b) can be collected efficiently; (c) enabling better service quality. Sixth, broaden the basis for retribution receipts. It is necessary to identify new or potential retribution payments, improve the object database, improve assessments, calculate the revenue capacity of each type of levy. Seventh, strengthen the collection process. Efforts that can be made in this context include accelerating the preparation of related regional regulations, changing tariffs and increasing human resources. Changes in tariffs in the context of waste retribution need to be considered by the polluters pays principle. In this theory, increasing the tariff for polluters or in the context of waste, increasing the retribution for waste producers who exceed the standardization limits that have been determined.

Eighth, increase supervision. Supervision is important so that there is a process that supports the enforcement of retribution regulations and sanctions for violators and makes administrative efficiency and reduces collection costs. This can be achieved by simplifying the administration of levies collection.

\section{Juridical Foundation}

In connection with the juridical basis that is used as the basis for the preparation of the Raperda of Public Service Retribution on Waste/Cleanliness, several legal references can be described as follows:

1. It is explained in Article 155 paragraph (1) of Law Number 28 of 2009 concerning Regional Taxes and Regional Levies, which contains that the Tariff of Charges is reviewed at the latest every 3 (three) years. So here it is very clear that Regional Regulations that have not updated 
their Regional Regulations are expected to be re-evaluated, both in adjusting the levy tariffs and managing and so on;

2. The values of Pancasila and the 1945 Constitution and must pay attention to the values of a comprehensive and comprehensive balance between rights and obligations that form the basis for determining the structure and amount of the Tariff for making Regional Regulations (Perda), so that legal arrangements made to reflect as well as reflect the harmony of balance;

3. A review of levy rates is carried out by taking into account economic developments and also the price index. This is in accordance with what is contained in Article 155 paragraph (2) of Law Number 28 of 2009;

4. Whereas regional levies/regional levies must be stipulated by a Regional Regulation (Perda) this is based on Article 156 paragraph (1) of Law Number 28 of 2009 concerning Regional Taxes and Regional Levies;

5. In Article 12 paragraph (1) of Law Number 18 of 2008 concerning Waste Management which states that everyone in the management of household waste and waste similar to household waste is obliged to reduce and handle waste in an environmentally sound manner. As in line with Article 35 paragraph (1) of the Regional Regulation of Bogor Regency Number 2 of 2014 concerning Waste Management, it is stated that the community is obliged to reduce production and handle waste in an environmentally sound manner. In this regard regarding the obligation to reduce waste, the Government provides incentives to everyone who reduces waste, and disincentives to everyone who does not reduce waste, as contained in Article 21 of Law Number 18 of 2008 concerning Waste Management and Article 43 of Regulation Bogor Regency Number 2 of 2014 concerning Waste Management.

\section{Conclusion}

That it is necessary to adjust the levy rates, especially regarding the general service retribution regarding cleaning/waste services. This is as explained in Article 155 paragraph (1) of Law Number 28 of 2009 concerning Regional Taxes and Regional Levies, which states that the Levy Tariff is reviewed at the latest every 3 (three) years. So here it is very clear for Regional Regulations that many regions have not yet updated their Regional Regulations, and are expected to be re-evaluated due to economic developments and also the price index. And the need for community participation in the formation of laws and regulations in this case is a regional regulation with the aim that it can be implemented in accordance with the needs to be achieved.

\section{References}

Asshiddiqie, Jimly. (2011). Konstitusi dan Konstitusionalisme Indonesia [Indonesian Constitution and Constitutionalism]. Jakarta: Sinar Grafika.

Fuady, M. (2014). Teori-Teori Besar (Grand Theory) Dalam Hukum [Grand Theory in Law]. Jakarta: Kencana Prenamedia Group.

Hoesein, Arifin Zainal. (2012). "Pembentukan Hukum Dalam Perspektif Pembaruan Hukum" [Formation of Law in the Perspective of Legal Reform]. https://rechtsvinding .bphn.go.id/ejournal/index.php/jrv/article/view/87. Jurnal Recht Vinding Volume 1 Nomor 3, Desember 2012.

Haqqi, Luthfan, Hibatul dan Nugroho, Asianto. (2020). "Pelaksanaan Retribusi Sampah Di Kota Surakarta" [Implementation of Waste Retribution in Surakarta City] https://jurnal.uns.ac.id/discretie/article/view/50270. Jurnal Discretie Vol 1, No 32020. 
Lathif, Nazaruddin, Suhermanto, dan Raden Muhmmad Mihradi. (2021) "Tinjauan Urgensi Perubahan Peraturan Daerah (Perda) Kabupaten Bogor Nomor 28 Tahun 2011 Tentang Retribusi Jasa Umum Mengenai Retribusi Persampahan/Kebersihan" [Review of the Urgency of Amendment to Regional Regulation (Perda) of Bogor Regency Number 28 of 2011 concerning Public Service Retribution Regarding Garbage/Cleaning Retribution]. https://journal.unpak.ac.id/index.php/palar/arti cle/view/3578, Jurnal Pakuan Law Review (Palar) Vol 7, No 22021.

Republik Indonesia. (1945). Undang-Undang Dasar Tahun 1945 [1945 Constitution]. Jakarta: Sekretariat Negara Republik Indonesia.

Republik Indonesia. (2008). Undang-Undang Nomor 18 Tahun 2008 tentang Pengelolaan Sampah [Law Number 18 of 2008 concerning Waste Management]. Jakarta: Sekretariat Negara Republik Indonesia.

Republik Indonesia. (2009). Undang-Undang Nomor 28 Tahun 2009 tentang Pajak Daerah dan Retribusi Daerah [Law Number 28 of 2009 concerning Regional Taxes and Regional Levies]. Jakarta: Sekretariat Negara Republik Indonesia.

Republik Indonesia. (2014). Undang-Undang Nomor 23 Tahun 2014 tentang Pemerintahan Daerah [Law Number 23 of 2014 concerning Local Government]. Jakarta: Sekretariat Negara Republik Indonesia.

SF, Marbun Dan Md, Mahmud M. (1987). Pokok-Pokok Hukum Administrasi Negara [Fundamentals of State Administrative Law]. Yogyakarta: Liberty. 1987.

Syarifin, Pipin dan Jubaedah, Dedah. (2005). Hukum Pemerintahan Daerah [Local Government Law]. Bandung: Pustaka Bani Quraisy. 2005.

Sabarno, Hari. (2008). Untaian Pemikiran Otonomi Daerah. Memandu Otonomi Daerah Menjaga Kesatuan Bangsa [Regional Autonomy Thought. Guiding Regional Autonomy to Maintain National Unity]. Jakarta: Sinar Grafika. 2008.

Sibuea, P Hotma. (2010). Asas Negara Hukum, Peraturan Kebijakan, Asas-Asas Umum Pemerintahan Yang Baik [Rule of Law Principles, Policy Regulations, General Principles of Good Governance]. Jakarta: Erlangga. 2010.

Sugara, Asep dan Kustuono, Dedy. (2019). "Evaluasi Pendapatan Asli Daerah Berdasarkan Retribusi Pelayanan Sampah Di Kota Tangerang" [Evaluation of Regional Original Income Based on Retribution for Waste Services in Tangerang City]. https://media.neliti.com/media/publications/299395-evaluasi-pendapatan-asli da erah-berdasaraf563d06.pdf. Jurnal Moziak Volume XI Edisi 2 Desember 2019.

\section{Copyrights}

Copyright for this article is retained by the author(s), with first publication rights granted to the journal.

This is an open-access article distributed under the terms and conditions of the Creative Commons Attribution license (http://creativecommons.org/licenses/by/4.0/). 